\title{
KORELASI ANTARA PERSEPSI SISWA TENTANG INOVASI GURU DALAM PEMBELAJARAN MATEMATIKA DENGAN MOTIVASI BELAJAR SISWA KELAS VIII SMPN 5 PALLANGGA KABUPATEN GOWA
}

\author{
Yulianti J1), Muljono Damopoli2), Ulfiani Rahman ${ }^{3)}$ \\ 1,2,3Fakultas Tarbiyah dan Keguruan UIN Alauddin Makassar \\ 1,2,3Kampus II: Jalan H. M. Yasin Limpo Nomor 36 Samata-Gowa \\ E-mail: yulianti@yahoo.com²), muldafat@uin-alauddin.ac.id²), \\ ulfiani.rahman@uin-alauddin.ac.id3)
}

\begin{abstract}
Abstrak:
Penelitian ini bertujuan untuk mengetahui korelasi antara persepsi siswa tentang inovasi guru dalam pembelajaran matematika dengan motivasi belajar siswa kelas VIII SMPN 5 Pallangga Kabupaten Gowa. Jenis penelitian ini adalah deskriptif korelasional dengan desain penelitian paradigma sederhana. Instrumen yang digunakan dalam penelitian ini adalah angket inovasi guru dalam pembelajaran matematika dan angket skala motivasi belajar siswa. Teknik analisis yang digunakan adalah analisis statistik deskriptif dan analisis statistik inferensial dengan menggunakan analisis korelasi person. Berdasarkan analisis statistik deskriptif diperoleh gambaran persepsi siswa tentang inovasi guru dalam pembelajaran matematika berada pada kategori sedang dengan persentase sebesar $66 \%$, dan gambaran motivasi belajar siswa berada pada kategori sedang dengan persentase sebesar 66\%. Berdasarkan analisis statistik inferensial dengan menggunakan analisis korelasi person menunjukkan bahwa persepsi siswa tentang inovasi guru dalam pembelajaran matematika dengan nilai sig. sebesar 0,003. Kemudian dibandingkan dengan probabilitas 0,01, ternyata nilai Sig. $\leq 0,05$ yaitu $0,003 \leq 0,05$, maka hal ini menunjukkan bahwa $\mathrm{H}_{0}$ ditolak sehingga dapat disimpulkan bahwa terdapat korelasi antara inovasi guru dalam pembelajaran matematika dengan motivasi belajar siswa. Berdasarkan angka kolerasinya yaitu 0,291 , dalam hal ini korelasi antara persepsi siswa tentang inovasi guru dalam pembelajaran matematika dengan motivasi belajar siswa kelas VIII SMPN 5 Pallangga Kabupaten Gowa berkorelasi positif dengan korelasi yang rendah.
\end{abstract}

Kata Kunci: Inovasi Guru, Motivasi Belajar

$\mathrm{P}$ endidikan merupakan kebutuhan mutlak bagi kehidupan manusia yang harus dipenuhi sepanjang hayat. Tanpa pendidikan, kehidupan manusia mustahil dapat berkembang secara baik. Pendidikan dapat diartikan sebagai proses dengan menggunakan metode tertentu sehingga seseorang akan mendapatkan pengetahuan, pemahaman, dan cara bertingkah laku yang sesuai dengan kebutuhan manusia (Lailia, 2012: 16). 
Untuk itu pemerintah, khususnya Departemen Pendidikan Nasional, harus berupaya keras untuk meningkatkan mutu pendidikan. Sebab, peningkatan kualitas sumber daya manusia harus dimulai dari peningkatan mutu pendidikan. Sejarah telah mencatat dan telah membuktikan bahwa manusia yang berkualitas hanya dimiliki oleh manusia yang berpendidikan. Kualitas kehidupan bangsa sangat ditentukan oleh faktor pendidikan. Peran pendidikan sangat penting untuk menciptakan kehidupan yang cerdas, damai, terbuka, dan demokratis. Oleh karena itu, pembaruan pendidikan harus selalu dilakukan untuk meningkatkan kualitas pendidikan nasional (Lestari, 2010:2).

Peran pendidikan begitu penting untuk meciptakan generasi muda yang berkualitas, berakhlak mulia dan berbudi pekerti luhur. Namun untuk meningkatkan mutu pendidikan maka diperlukan pula peran seorang guru yang akan mendidik anak-anak di sekolah.

Guru merupakan pemimpin utama dari perubahan dalam pendidikan, maka jelas bahwa keterlibatan dan kesediaan mereka untuk secara aktif berpartisipasi dalam kehidupan sekolah sebagian besar bergantung pada kualitas proses dan hasil yang dicapai disemua tingkat pendidikan. Guru adalah orang yang sangat berpengaruh. Oleh karena itu, guru harus mampu membawa siswanya kepada tujuan yang ingin dicapai dari proses pembelajaran, sehingga guru perlu melakukan pembaruan terhadap perencanaan maupun pelaksanaan proses belajar mengajar, mencakup bahan ajar, metode dan pendekatan, sarana dan prasarana, serta keterampilan dasar mengajar. Kualitas pembelajaran juga dilihat dari aktivitas peserta didik ketika belajar dan kreatifitas yang dapat dilakukan oleh peserta didik setelah mengikuti pembelajaran (Ta'rifin, 2009: 3).

Guru tidak semata-mata berperan sebagai "pengajar" yang mentransfer pengetahuan (transfer of knowledges) saja, tetapi juga sebagai "pendidik" yang mentransfer nilai-nilai (transfer of values) dan sebagai "pembimbing" (counselor) yang memberikan pengarahan dan menuntun siswanya dalam proses pembelajaran. Banyak hal yang mempengaruhi keberhasilan proses belajar mengajar, salah satunya motivasi belajar siswa. Motivasi belajar sangat dibutuhkan untuk tercapainya proses pembelajaran terutama dalam pelajaran matematika, matematika sebagai suatu disiplin ilmu yang melatih siswa untuk berpikir secara logis, rasional, kritis, dan cermat harus mampu menopang kemajuan pendidikan nasional. Untuk itu, Kegiatan proses belajar mengajar harus dilakukan dengan cara yang menarik dan menyenangkan dalam rangka menumbuhkan motivasi belajar siswa, yang tidak lain adalah guru hendaknya 
melakukan inovasi disetiap pembelajarannya. Motivasi belajar siswa dapat tumbuh apabila didukung oleh tenaga pendidik yang cakap, terampil dan inovatif (Baumert, 2010: 134).

Namun faktanya pembelajaran yang dilakukan oleh guru pada umumnya masih berpusat pada guru. Dimana seorang guru dalam menyampaikan pembelajarannya masih monoton terhadap cara-cara lama dalam proses belajar mengajar, maka lama kelamaan akan mengurangi ketertarikan terhadap apa yang disampaikan oleh guru, serta menimbulkan kebosanan dan rasa mengantuk yang dampaknya tentu saja tujuan pembelajaran tidak tercapai. Mengingat bahwasanya, pelajaran matematika yang merupakan cabang ilmu eksak yang membutukan tingkat pemahaman tersendiri dibandingkan ilmu-ilmu lainnya, sekaligus cabang ilmu hitung yang kurang diminati sebagian besar siswa, karena menjadi salah satu pelajaran yang membosankan, dan momok menakutkan, sebab pemecahan masalahnya begitu sulit untuk dipahami. Untuk itu, guru perlu mensiasati pelajaran tersebut dengan melakukan inovasi saat mengajar di kelas.

Untuk memperkuat paradigma tersebut peneliti telah melakukan observasi di SMPN 5 Pallangga Kabupaten Gowa. Peneliti memperoleh keterangan bahwa terdapat kesulitan siswa dalam belajar matematika karena kurang motivasi belajarnya, di lihat dari proses belajar mengajar yang sedang berlangsung, jumlah peserta didik yang mengikuti pelajaran dengan baik hanya sekitar 70\%, jadi sekitar 30\% siswa tidak mengikuti proses pembelajaran dengan baik. Untuk mengetahui kebenaran dari hal tersebut, peneliti mencoba untuk menyelidiki apakah terdapat korelasi antara inovasi guru dalam pembelajaran matematika dengan motivasi belajar siswa.

Berdasarkan penelitian sebelumnya yang relevan dilakukan oleh Sofyan Iskandar diperoleh hasil penelitian bahwa terdapat hubungan yang signifikan antara kemampuan pembelajaran dengan keinovatifan guru, sehingga dapat diprediksi bahwa makin tinggi tingkat keinovatifan guru, maka makin baik pula kemampuan mengelola pembelajarannya (Widoyoko, 2012:1).

Berdasarkan uraian yang telah dikemukakan di atas, maka penulis tertarik untuk meneliti masalah tentang "Korelasi antara Inovasi Guru dalam Pembelajaran Matematika dengan Motivasi Belajar Siswa Kelas VIII SMPN 5 Pallangga Kabupaten Gowa." 


\section{PERSEPSI}

Persepsi adalah suatu proses yang didahului oleh penginderaan, yaitu merupakan proses diterimanya stimulus oleh individu melalui alat indera atau reseptornya dan stimulus itu diteruskan ke saraf dan terjadinya proses psikologi, sehingga individu menyadari adanya apa yang ia lihat, apa yang didengar (Walgito, 2002: 69). Menurut Irwanto, persepsi adalah proses diterimanya rangsangan obyek kualitas, hubungan antara gejala maupun peristiwa sampai rangsangan itu disadari dan dimengerti, karena persepsi bukan sekedar penginderaan, maka ada yang menyatakan persepsi sebagai the interpretation of experience (Irwanto, 1994: 71).

\section{INOVASI}

Menurut Rogers inovasi adalah gagasan, praktek, atau objek yang dianggap baru oleh seorang individu atau unit adopsi lainnya. Sedangkan pengertian inovasi dalam konteks pendidikan dan pembelajaran berhubungan dengan pengetahuan-pengetahuan baru yang berhubungan dengan suatu mata pelajaran tertentu, metode atau strategi pembelajaran baru, strategi mengorganisasikan bahan pelajaran, strategi penyampaian, dan sebagainya. Proses keputusan inovatif menurut Rogers melewati lima tahap yaitu: (1) tahap pengetahuan, (2) tahap persuasi, (3) tahap keputusan, (4) tahap implementasi, dan (5) tahap konfirmasi (Iskandar, 2008: 2).

\section{GURU}

Salah satu faktor utama yang menentukan mutu pendidikan adalah guru. Gurulah yang berada di garda terdepan dalam menciptakan kualitas sumber daya manusia. Guru berhadapan langsung dengan para peserta didik di kelas melalui proses belajar mengajar. Karena pekerjaan guru adalah pekerjaan yang mulia maka untuk menjadi guru harus pula memenuhi beberapa persyaratan seperti (a) harus memiliki bakat sebagai guru, (b) harus memilki keahlian sebagai guru, (c) memiliki keahlian yang baik dan terintegrasi, (d) memilki mental yang sehat, (e) berbadan sehat, (f) memilki pengalaman dan pengetahuan yang luas, (g) guru adalah manusia berjiwa pancasila, dan h) guru adalah seorang warga sosial yang baik (Hamalik, 2009: 121). 


\section{INOVASI GURU DALAM PEMBELAJARAN MATEMATIKA}

Kemampuan Inovasi yang dimiliki oleh seorang guru akan meningkatkan kualitas seorang guru yang bersangkutan. Proses pembelajaran pun akan berjalan lebih baik. Oleh karena itu, sudah menjadi keharusan bagi guru untuk dapat menciptakan inovasi-inovasi pembelajaran agar produk pembelajarannya berkualitas dan peserta didik semakin pintar.

Indikator inovasi guru dalam pembelajaran matematika adalah:

\section{a. Pengelolaan Kelas}

Pengelolaan kelas terdiri dari dua kata yaitu pengelolaan dan kelas. Pengelolaan kelas itu sendiri kata dasarnya adalah kelola ditambah awalan "pe" dan akhiran "an". Istilah lain dari kata pengelolaan adalah "manajemen". Manajemen berasal dari bahasa Inggris yaitu "management", yang berarti ketatalaksanaan, tata pimpinan, pengelolaan. Manajemen atau pengelolaan dalam pengertian umum menurut Arikunto adalah pengadministrasian, pengaturan atau penataan suatu kegiatan (Zain \& Djamarah, 2002: 196).

b. Media Pembelajaran

Media merupakan perantara atau pengantar pesan dari pengirim ke penerima pesan. Gagne menyatakan media adalah berbagai jenis komponen pembelajaran merupakan proses berlangsungnya belajar mengajar (Raharjo, 1997: 7).

c. Metode Pembelajaran

Metode pembelajaran adalah suatu cara atau jalan yang ditempuh yang selaras dan serasi untuk menyajikan suatu hal sehingga akan tercapai suatu tujuan pembelajaran yang efektif dan efisien sesuai yang diharapkan.

\section{MOTIVASI BELAJAR}

Motivasi sendiri merupakan dorongan dasar yang menggerakkan untuk melakukan sesuatu yang sesuai dengan dorongan dalam dirinya. Seperti yang dikemukakan oleh Sardiman bahwa kata "motif", diartikan sebagai daya upaya yang mendorong seseorang untuk melakukan sesuatu. Motif dapat dikatakan sebagai daya penggerak dari dalam (intrinsik) dan di luar (ekstrinsik) subjek untuk melakukan aktivitas-aktivitas tertentu demi mencapai suatu tujuan. Pendapat lain mengemukakan bahwa, motivasi adalah suatu perubahan energi di dalam pribadi seseorang yang ditandai dengan timbulnya perasaan dan reaksi untuk mencapai tujuan. Perubahan energi dalam diri seseorang itu berbentuk suatu aktivitas nyata berupa kegiatan fisik (Djamarah, 2011: 148). 


\section{METODE PENELITIAN}

Jenis penelitian yang digunakan yaitu penelitian deskriptif korelasional. Untuk mendeteksi sejauh mana variasi-variasi pada suatu faktor berkaitan dengan variasi-variasi pada satu atau lebih faktor lain berdasarkan pada koefisien korelasi (Suryabrata, 2014: 82). Penelitian ini dilakukan di SMPN 5 Pallangga Kabupaten Gowa ini berlokasi di Desa Julubori, Dusun Borong Bilalang, Kecamatan Pallangga, Kabupaten Gowa. Pendekatan yang digunakan dalam penelitian ini yaitu pendekatan expost facto, yang bertujuan untuk menyelidiki kemungkinan hubungan sebab akibat berdasarkan pengamatan terhadap akibat yang ada, mencari kembali fakta yang mungkin menjadi penyebab melalui data tertentu. Adapun desain penelitan yang digunakan yaitu paradigma sederhana dengan satu variabel bebas $(X)$ dan satu variabel terikat $(\mathrm{Y})$.

Populasi dalam penelitian ini adalah seluruh siswa kelas VIII SMPN 5 Pallangga Kabupaten Gowa terdiri dari 7 kelas dengan jumlah siswa 258 orang, penentuan sampel dengan menggunakan teknik random sampling dengan cara undian, dimana semua anggota populasi mempunyai peluang yang sama untuk dimasukkan menjadi anggota sampel. Menurut Arikunto, apabila terdapat jumlah populasi lebih dari 100 maka sampel yang dapat diambil adalah 50\% dari sampel yang ada, sehingga jumlah sampel yang dibutuhkan dapat dihitung dengan cara 50\% × $258=103$ jadi, banyaknya sampel yang dibutuhkan adalah 3 kelas. Sehingga, yang menjadi sampel pada penelitian ini adalah kelas VIIIA, VIIIB, VIIIC. Alat bantu yang digunakan dalam penelitian yakni angket persepsi siswa tentang inovasi guru dalam pembelajaran matematika dengan motivasi belajar siswa. Ada dua macam statistik yang digunakan untuk analisis data dalam penelitian, yaitu statistik deskriptif dan statistik inferensial. Uji prasyarat dalam penelitian ini adalah uji normalitas, uji linearitas selanjutnya pengujian hipotesis. Untuk menguji ada tidaknya korelasi antara kedua macam variasi digunakan analisis Correlation Product Moment. Statistik inferensial digunakan untuk menguji hipotesis penelitian. Maka, untuk keperluan tersebut digunakan analisis Correlation Product Moment. 


\section{HASIL PENELITIAN DAN PEMBAHASAN}

Gambaran Persepsi Siswa tentang Inovasi Guru dalam Pembelajaran Matematika Siswa Kelas VIII SMPN 5 Pallangga Kabupaten Gowa

Tabel 1. Distribusi Frekuensi Kategorisasi Persepsi Siswa tentang Inovasi Guru dalam pembelajaran Matematika SMPN 5 Pallangga Kabupaten Gowa

\begin{tabular}{cccc}
\hline Interval & Frekuensi & Persentase & Keterangan \\
\hline $\mathrm{x}<59$ & 15 & $14,9 \%$ & Rendah \\
$59 \leq \mathrm{x}<9$ & 68 & $66,8 \%$ & Sedang \\
$79 \leq \mathrm{x}$ & 19 & $18,9 \%$ & Tinggi \\
\hline Total & 102 & $100 \%$ & \\
\hline
\end{tabular}

Pada tabel di atas menunjukkan hasil perhitungan distribusi frekuensi, diketahui 15 peserta didik atau 1,4\% yang menganggap inovasi guru dalam pembelajaran matematika berada pada kategori rendah. Terdapat 68 peserta didik atau 66,8\% yang menganggap inovasi guru dalam pembelajaran matematika berada pada kategori sedang, serta terdapat 19 peserta didik atau $18,9 \%$ yang menganggap inovasi guru dalam pembelajaran matematika berada pada kategori tinggi.

\section{Gambaran Motivasi Belajar Siswa Kelas VIII SMPN 5 Pallangga Kabupaten Gowa}

Tabel 2. Distribusi Frekuensi Kategorisasi Motivasi Belajar Siswa Kelas VIII SMPN 5 Pallangga Kabupaten

\begin{tabular}{cccc}
\hline Interval & Frekuensi & Persentase & Keterangan \\
\hline$x<57$ & 17 & $16,8 \%$ & Rendah \\
$57 \leq x<73$ & 68 & $66,6 \%$ & Sedang \\
$73 \leq x$ & 17 & $16,7 \%$ & Tinggi \\
\hline Total & 102 & $100 \%$ & \\
\hline
\end{tabular}

Berdasarkan tabel di atas menunjukkan hasil perhitungan distribusi frekuensi, diketahui 17 peserta didik atau 16,8 \% peserta didik yang memiliki motivasi belajar berada pada kategori rendah. Terdapat 68 peserta didik atau $66,6 \%$ peserta didik yang memiliki motivasi belajar matematika berada pada kategori sedang, serta terdapat 17 peserta didik atau 16,7\% peserta didik yang memiliki tingkat motivasi belajar matematika berada pada kategori tinggi. 
Korelasi antara Persepsi Siswa tentang Inovasi Guru dalam Pembelajaran Matematika dengan Motivasi Belajar Siswa Kelas VIII SMPN 5 Pallangga Kabupaten Gowa

Pada bagian ini akan menjawab rumusan masalah yang terakhir dengan menggunakan statistik deskriptif inferensial sebagai berikut:

Uji normalitas pada persepsi siswa tentang inovasi guru dalam pembelajaran matematika kelas VIII SMPN 5 Pallangga Kabupaten Gowa menggunakan taraf signifikansi sebesar $a=0,05$. Berdasarkan hasil pengolahan menggunakan SPSS 20 maka diperoleh pada hasil output nilai Kolmogorov-smirnov dengan signifikansi sebesar $\operatorname{Sig}=0,352$ dengan demikian Sig $=0,352 \geq a=0,05$ sehingga data inovasi guru dalam pembelajaran matematika berdistribusi normal. Uji normalitas pada data motivasi belajar siswa juga menggunakan taraf signifikansi sebesar $a=0,05$. Berdasarkan hasil pengelolaan menggunakan SPSS 20 maka diperoleh pada hasil output nilai Kolmogorov-smirnov dengan signifikansi sebesar $\operatorname{Sig}=0,498$ dengan demikian Sig $=0,489 \geq a=0,05$ sehingga data motivasi belajar siswa berdistribusi normal.

Uji linieritas dalam penelitian ini dilakukan dengan menggunakan analisis varians. Kaidah yang digunakan jika F signifikan. Uji linieritas tentang inovasi guru dalam pembelajaran matematika dengan motivasi belajar siswa kelas VIII SMPN 5 Pallangga Kabupaten Gowa program SPSS versi 20. Hasil uji linieritas persepsi siswa tentang inovasi guru dalam pembelajaran matematika dengan motivasi belajar siswa diperoleh hasil sig. 0,001< $\alpha$ berarti data persepsi siswa mengenai inovasi guru dalam pembelajaran matematika dengan motivasi belajar siswa adalah linear.

Pengujian yang dilakukan untuk mengetahui hubungan antara persepsi siswa tentang inovasi guru dalam pembelajaran matematika dengan motivasi belajar siswa digunakan uji korelasi person. Berdasarkan hasil uji SPSS 20, korelasi antara persepsi siswa tentang inovasi guru dalam pembelajaran matematika dengan motivasi belajar siswa kelas VIII SMPN 5 Pallangga menunjukkan bahwa variabel inovasi guru dalam pembelajaran matematika dengan nilai sig. sebesar 0,003 . Kemudian dibandingkan dengan probabilitas 0,01 , ternyata nilai Sig. $\leq 0,05$ yaitu $0,003 \leq 0,05$, maka hal ini menunjukkan bahwa $\mathrm{H}_{0}$ ditolak sehingga dapat disimpulkan bahwa terdapat korelasi antara inovasi guru dalam pembelajaran matematika dengan motivasi belajar siswa. Berdasarkan angka kolerasi yaitu 0,291 ini berarti bahwa kolerasi antara 
inovasi guru dalam pembelajaran matematika dengan motivasi belajar siswa memiliki korelasi yang rendah.

\section{SIMPULAN}

Berdasarkan hasil penelitian dan pembahasan, maka dapat ditarik kesimpulan bahwa persepsi siswa tentang inovasi guru dalam pembelajaran matematika memiliki hubungan yang signifikan dan positif dengan motivasi belajar siswa kelas VIII SMPN 5 Pallangga Kabupaten Gowa. Apabila inovasi guru dalam pembelajaran matematika tinggi, maka motivasi belajar siswa kelas VIII SMPN 5 Pallangga Kabupaten Gowa akan meningkat pula.

\section{DAFTAR PUSTAKA}

Baumert, J. (2010). Teachers' mathematical knowledge, cognitive activion in the classroom, and student progres, American Education Research Jurnal, 47(1), 134-181.

Djamarah, Bahri, S. \& Zain, A. (2002). Strategi belajar mengajar. Cet. 2; Jakarta: PT. Rineka Cipta.

Hamalik, O. (2009). Proses belajar mengajar. Cet. X; Jakarta: Bumi Aksara.

Iskandar, S. (2008). Kemampuan pembelajaran dan keinovatifan guru. Jurnal Pendidikan, 9, 1-5.

Irwanto. (1994). Psikologi umum. Jakarta: Gramedia Pustaka Utama.

Lestari, S. (2010). Peningkatan hasil belajar matematika melalui pendekatan kontekstual pada siswa kelas II SD Negeri III Bubukan Kec. Girimarto Kab. Wonogiri. Skripsi. Surakarta: Fak. Keguruan dan Ilmu Pendidikan Universitas Sebelas Maret. Jakarta: Gema Insani Press.

Lailia, H. (2012). Nilai-nilai optimesme dan implikasinya terhadap motivasi belajar anak dalam film hafalan sholat delisa karya sutradara sony gaokasak. Skripsi. Yogyakarta: Fak. Tarbiyah dan Keguruan Universitas Islam Negeri Sunan Kalijaga.

Raharjo. (1993). Media pendidikan. Jakarta: Grafindo.

Suryabrata, S. (2014). Metodologi penelitian. Jakarta: PT Raja Grafindo Persada. 
Yulianti J1), Muljono Damopoli2), Ulfiani Rahman ${ }^{3)}$

Ta'rifin, A. (2009). Membangun interaksi humanistik dalam proses pembelajaran, forum tarbiyah, 7(1), 3 .

Widoyoko, E. P. (2012). Pengaruh kinerja guru terhadap motifasi belajar siswa. Cakrawala Pendidikan.

Walgito, B. (2002). Pengantar Psikologi umum. Yogyakarta: Andi Offset. 